\title{
Defect in Posterior Arch of Atlas in Myelomeningocele
}

\author{
G. BLAAUW
}

In the course of an investigation not closely connected to this present paper, we accidentally came across an anomaly of the posterior arch of the atlas which was common in children with myelomeningocele.

\section{Material and Methods}

We examined 30 spines from necropsies carried out at the Children's Hospital, Sheffield, and at the Academic Hospital Dijkzigt, Rotterdam, on children who had died with a myelomeningocele in the lower thoracic, lumbar or sacral region. There was a greater incidence of female children in the group with thoracolumbar or lumbar myelomeningoceles; the sex distribution was broadly the same when the myelomeningocele was situated on the lumbosacral joint or in the sacral region.

The specimens were randomly chosen from a large stock. The foramen magnum and the posterior arches of the cervical vertebrae were dissected. The dura was left intact. When a defect existed in the posterior arch of the atlas, this was measured with calipers. Roentgenograms were taken of a few spines. Long exposure times and a $0.3 \mathrm{~mm}$ focal spot were used. The patients' ages varied from 1 day to $4 \frac{1}{2}$ years.

\section{Findings}

In 21 of the 30 spines a defect existed in the posterior arch of the atlas (Fig. 1). The width of the defect varied from $3 \mathrm{~mm}$ to $7.5 \mathrm{~mm}$ (mean $4.75 \mathrm{~mm}$ ). The defect was bridged in all the cases by a fibrous band, distinct from the surrounding tissue and firmly attached to the club-shaped free ends of the posterior arch of the atlas. Microscopic examination of one specimen revealed an abundance of elastic fibres in the fibrous band.

There appeared to be no relationship between the defect and head circumference, crownrump length, weight or age. As a rule, an atlas defect was present in the cases with a thoracolumbar or lumbar myelomeningocele. Since the proportion of females seems to be particularly high in these cases, it is not surprising that there was a predominance of female children with an atlas defect in our group.

In 6 of the 21 cases there were also small defects in the posterior arches of some lower cervical vertebrae, and in 2 cases there was fusion of a posterior arch with a consecurive one. In none of these cases were the other defects bridged like those in the atlas. In one case the left part of the posterior arch of the atlas was hypoplastic: it consisted of a bony centre, attached by fibrous tissue to the lateral process. In none of the cases was there a defect of the axis.

\section{Discussion}

There have been numerous reports of congenital abnormalities of the atlas, and non-

Department of Neurosurgery, Academic Hospital Dijkzigt, Rotterdam, The Netherlands. 


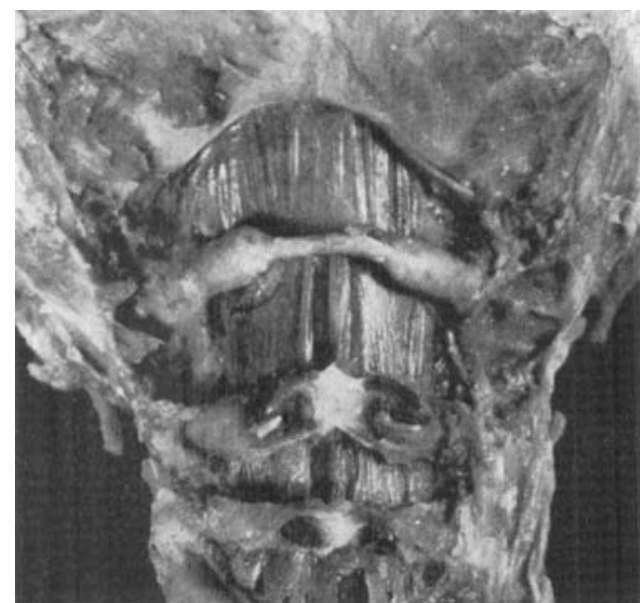

Fig. 1. View of the back of the neck with the posterior arches dissected. Part of the occipital bone with the rim of the foramen magnum is seen at the top of the picture. The defect in the atlas and the fibrous band show clearly.

union of the posterior arch of the atlas has been mentioned in radiological studies in adults. In the young child, roentgenograms cannot be relied on to give evidence of a defect, for complete ossification of the cartilaginous vertebrae is sometimes only reached in the sixth or seventh year. The club-shaped free ends of the posterior arch, however, may indicate a defect with a fibrous band on the roentgenogram (Fig. 2). Both ends show clearly, particularly when the X-ray beam is slightly oblique.

In adults, the incidence of defects in the posterior arch of the atlas seems to be 4 per cent (Geipel 1955). Out of 24 children with spina bifida, Geipel found atlas defects in 12 cases, with a predominance of females. We found an even greater preference for the female sex. A relationship with the site of the myelomeningocele also appeared to exist in Geipel's

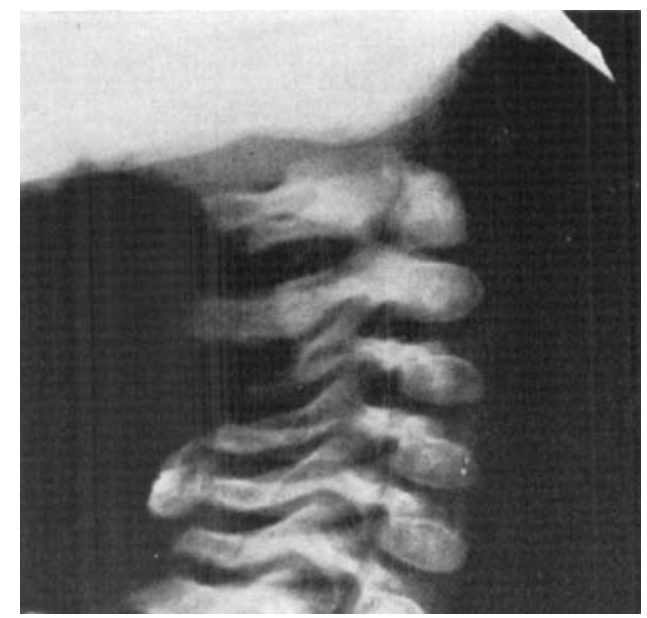

Fig. 2. Lateral roentgenogram of the upper part of the spine in lumbar myelomeningocele. The club-shaped free ends of the posterior arch of the atlas indicate a defect with a fibrous band. 
series. The defects found in adults were bridged by a fibrous band, which often contained elastic fibres (Geipel 1935). Barbosa Sueiro (1933) found an incidence of 3 per cent in a series of 400 spines.

In children, Geipel considers replacement of part of the posterior arch of the atlas by a fibrous band as a true and permanent defect. In all other cases, he assumes that sooner or later, and certainly before the seventh year, ossification of the cartilaginous bone will occur, or that only small fissures will remain.

Although the defect in the posterior arch of the atlas does not seem to be of any clinical significance, it is an interesting coincidence. It is generally assumed nowadays that spina bifida aperta is a disease of the whole central nervous system with allied abnormalities of its bony compartments. This assumption is supported by our present findings.

Acknowledgements: The author wishes to thank Dr. J. L. Emery, Sheffield, for his stimulation and hospitality. Photographs by Mr. A. Tunstill, Sheffield, and by the Audio-Visual Department, Medical Faculty, Rotterdam. This study was supported by a grant from the Netherlands Organization for the Advancement of Pure Research (Z.W.O.).

\section{SUMMARY}

The posterior arches of the cervical vertebrae of 30 children who died with a myelomeningocele in the lower thoracic, lumbar or sacral region were examined; in 70 per cent of these cases a defect was found in the posterior arch of the atlas, which was bridged by a firm fibrous band.

\section{RÉSUME}

Altération de l'arc postérieur de l'atlas dans le myéloméningocèle

Les arcs postérieurs des vertèbres cervicales de 30 enfants décédés avec un myéloméningocèle des régions thoracique basse, lombaire ou sacrée ont été examinés. Il a été trouvé dans 70 pour cent des cas, une altération de l'arc postérieur de l'atlas avec un pont fibreux solide.

\section{ZUSAMMENFASSUNG}

Defekt des hinteren Atlasbogens bei der Myelomeningocele

Die Hinterbogen der Halswirbelkörper von 30 Kindern, die an einer Myelomeningocele der unteren thorakalen, lumbären oder Sakralgegend gestorben waren, wurden untersucht; in 70 Prozent dieser Fälle fand sich ein Defekt des hinteren Atlasbogens, der durch ein festes fibröses Band gedeckt war.

\section{RESUMEN}

\section{Defecto en el arco posterior del atlas en el mielomeningocele}

Se examinaron los arcos posteriores de las vértebras cervicales en 30 niños que fallecieron con un mielomeningocele en la region torácica baja, lumbar o sacra. En el 70 por ciento de estos casos se encontró un defecto en el arco posterior del atlas, con la presencia de un puente formado por una banda fibrosa firme.

\section{REFERENCES}

Barbosa Sueiro, M. B. (1933) 'Sur l'osselet odontoidien de l'axis humain.' Arch. Anat. Antrop. (Lisboa) 16,135 .

Geipel, P. (1935) 'Zur Kenntnis der Spaltbildung des Atlas und Epistropheus.' Fortschr. Roentgenstr., 52, 533. - (1955) 'Zur Kennt nis des Spaltbildung des Atlas und Epistropheus.' Zhl. allg. Path. path. Anat., $94,19$. 